\title{
Air Quality Index in Iasi City
}

\author{
Ana Maria OISTE ${ }^{1 *}$ \\ ${ }^{1}$ Department of Hydrotechnics , Geodesy and Environmental Engineering. University of Iasi, Romania. \\ * corresponding author: anamaria.oiste@usamvcluj.ro
}

Bulletin USAMV series Agriculture 72(1)/2015

Print ISSN 1843-5246; Electronic ISSN 1843-5386

DOI 10.15835/buasvmcn-agr: 11189

\begin{abstract}
Air quality index represents an innovative methods to present the air quality to wide public, that have not scientific knowledges concerning air quality. The aim of study is to presents the methods and the results concerning air quality index for Iasi city.
\end{abstract}

Keywords: air, Iasi city, index.

\section{INTRODUCTION}

The analysis of the air quality parameters indicates a series of multiannual, seasonal and monthly variations in the period under discussion (2006 - 2011), in agreement with the nature of the city main activities, being influenced by a number of natural factors (relief, vegetation, etc) as well as by anthropogenic factors. The spatial variation of air pollutants was highlighted by the analysis of the observations in 5 monitoring sites; being relevant, because the Iasi city is one of the largest cities of Romania, so that the impacted population by air pollution is larger

\section{AIMS AND OBJECTIVES}

The aim of current study is to presents the air pollution in an accessible manner for population, no matter the education level, that will be able to understand the danger after seeing a coloured table.

\section{MATERIALS AND METHODS}

The database was elaborated from the annual reports for the environmental status issued by APM Iasi, for the monthly and annual average values, as well as the daily average values for the six pollutants under analysis. The database was analyzed and processed statistically and the annual and monthly average values were determined, and
Air pollution index was computed according to the formula:

$$
\boldsymbol{I}_{\boldsymbol{p}}=(-1) \times 100 \times \frac{(C-C M A)}{(C+C M A)}
$$

where:

$\mathrm{C}=$ Registered concentration of a pollutant

$\mathrm{CMA}=$ Maximum average concentration

The results were divided between several classes according the limits from the methodology: $\mathrm{PP}=-15$ (danger limit)

$\mathrm{PI}=0$ (intervention limit)

$\mathrm{PA}=15$ (alert limit)

$\mathrm{PM}=70$ (limit of starting monitoring)

\section{RESULTS AND DISCUSSION}

Air quality in the town of Iasi has been monitored through five different stations since 2005 , and it provides information on annual, seasonal, monthly, daily and hourly variation of the main categories of air pollutants: inorganic pollutants (compounds of sulphur, nitrogen, carbon, secondary pollutants of which the most important is the tropospheric $\mathrm{O}_{3}$ ), organic pollutants $\left(\mathrm{C}_{6} \mathrm{H}_{6}\right)$ and particulate matter pollutants.

The average values of air pollutants for the period $2006-2011$ are: $5.76 \pm 0.7 \mu \mathrm{g} / \mathrm{cm} 3 \mathrm{SO}$, 
Tab 1: Air quality index results

\begin{tabular}{|c|c|c|c|c|c|c|c|c|c|c|c|c|c|}
\hline & & I & II & III & IV & V & VI & VII & VIII & IX & $\mathrm{X}$ & XI & XII \\
\hline \multirow{6}{*}{ 尺̃ } & IS 1 & 87.2 & 87.3 & 90.2 & 91.3 & 92.9 & 92.4 & 92.8 & 92.7 & 91.8 & 89.9 & 89.2 & 88.7 \\
\hline & IS 2 & 88.6 & 87.9 & 90.8 & 92.8 & 93.8 & 94.0 & 93.9 & 93.1 & 92.5 & 90.9 & 90.5 & 89.8 \\
\hline & IS 3 & 89.5 & 85.8 & 89.1 & 92.5 & 93.4 & 93.5 & 93.1 & 93.8 & 92.4 & 92.2 & 91.4 & 90.1 \\
\hline & IS 4 & 87.4 & 87.3 & 92.3 & 93.5 & 94.2 & 93.8 & 93.0 & 93.6 & 92.6 & 91.8 & 91.5 & 88.5 \\
\hline & IS 5 & 84.6 & 87.5 & 90.8 & 92.2 & 93.5 & 92.8 & 92.8 & 92.4 & 92.3 & 92.2 & 91.4 & 89.8 \\
\hline & Average & 87.4 & 87.1 & 90.6 & 92.5 & 93.5 & 93.3 & 93.1 & 93.1 & 92.3 & 91.4 & 90.8 & 89.4 \\
\hline \multirow{6}{*}{$\stackrel{x}{0}$} & IS 1 & -46.3 & -42.7 & -41.1 & -33.8 & -27.3 & -22.9 & -25.5 & -28.1 & -41.3 & -51.7 & -49.6 & -52.5 \\
\hline & IS 2 & 15.1 & -9.0 & -1.2 & 7.8 & 20.3 & 23.3 & 26.4 & 18.4 & 0.0 & -20.4 & -23.1 & -15.1 \\
\hline & IS 3 & 9.3 & 13.8 & 22.9 & 31.3 & 44.4 & 45.6 & 42.8 & 37.4 & 22.1 & 9.0 & 2.2 & 10.1 \\
\hline & IS 4 & 51.1 & 58.2 & 63.2 & 69.0 & 73.6 & 70.4 & 70.3 & 66.9 & 64.3 & 57.1 & 49.2 & 47.8 \\
\hline & IS 5 & 4.4 & 4.1 & 19.1 & 37.2 & 48.3 & 54.5 & 51.4 & 53.4 & 36.8 & 20.8 & 4.4 & -3.7 \\
\hline & Average & -10.3 & -5.9 & 0.5 & 10.6 & 20.5 & 24.1 & 22.5 & 18.7 & 2.8 & -12.4 & -15.1 & -15.4 \\
\hline \multirow{4}{*}{ ㅇ } & IS 1 & 82.1 & 85.3 & 88.4 & 91.8 & 94.0 & 94.9 & 94.4 & 93.5 & 91.4 & 85.6 & 85.1 & 83.0 \\
\hline & IS 4 & 93.7 & 96.7 & 97.6 & 98.6 & 99.0 & 98.9 & 99.0 & 98.7 & 99.1 & 98.6 & 97.4 & 96.2 \\
\hline & IS 5 & 91.7 & 93.9 & 95.7 & 97.6 & 98.5 & 98.7 & 98.5 & 98.3 & 98.1 & 95.9 & 95.0 & 92.6 \\
\hline & Average & 89.0 & 91.8 & 93.8 & 95.9 & 97.1 & 97.5 & 97.3 & 96.8 & 96.1 & 93.2 & 92.3 & 90.4 \\
\hline \multirow{3}{*}{ 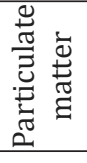 } & IS 1 & -31.4 & -17.4 & -14.7 & -13.2 & 3.4 & 5.3 & 1.8 & -7.4 & -14.0 & -34.9 & -34.4 & -23.3 \\
\hline & IS 3 & -13.1 & -2.4 & 5.5 & 13.2 & 31.7 & 31.5 & 22.7 & 7.1 & 18.4 & 1.0 & -1.1 & 3.5 \\
\hline & Average & -22.3 & -10.5 & -5.7 & -1.8 & 15.9 & 16.9 & 11.3 & -0.7 & -0.4 & -20.8 & -21.1 & -11.9 \\
\hline \multirow{3}{*}{ 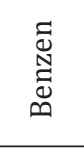 } & IS 1 & 7.0 & 11.4 & 11.8 & 27.5 & 39.0 & 42.9 & 46.8 & 35.3 & 27.5 & 11.3 & 6.7 & 8.8 \\
\hline & IS 2 & 8.2 & 20.1 & 39.7 & 45.5 & 57.8 & 60.8 & 62.0 & 54.4 & 42.3 & 21.4 & 19.5 & 14.7 \\
\hline & Average & 7.6 & 15.6 & 24.2 & 35.9 & 47.8 & 51.3 & 54.1 & 44.2 & 34.5 & 16.1 & 12.7 & 11.7 \\
\hline \multirow{4}{*}{$\begin{array}{l}0 \\
\text { ̃ } \\
\text { O }\end{array}$} & IS 3 & 59.4 & 49.9 & 39.2 & 35.2 & 35.4 & 39.4 & 39.1 & 42.5 & 55.7 & 64.4 & 69.0 & 68.5 \\
\hline & IS 4 & 44.0 & 38.7 & 26.4 & 21.0 & 23.8 & 27.4 & 28.4 & 27.9 & 34.5 & 43.2 & 46.2 & 53.5 \\
\hline & IS 5 & 53.4 & 47.6 & 35.3 & 33.4 & 31.0 & 33.8 & 32.7 & 39.7 & 52.7 & 61.6 & 63.1 & 67.5 \\
\hline & Average & 52.0 & 45.2 & 33.4 & 29.5 & 29.9 & 33.3 & 33.3 & 36.4 & 47.0 & 55.8 & 58.8 & 62.9 \\
\hline & & & & & & & & & PP & PI & PA & PM & $>\mathrm{PM}$ \\
\hline
\end{tabular}

$40.9 \pm 2.4 \mu \mathrm{g} / \mathrm{cm} 3 \mathrm{NOx}, 0.29 \pm 0.09 \mu \mathrm{g} / \mathrm{cm} 3 \mathrm{CO}$, $49.2 \pm 2.9 \mu \mathrm{g} / \mathrm{cm} 3 \mathrm{O} 3,2.87 \pm 0.72 \mu \mathrm{g} / \mathrm{cm} 3 \mathrm{C} 6 \mathrm{H} 6$, $42.31 \pm 13.04 \mu \mathrm{g} / \mathrm{cm} 3 \mathrm{PM} 10$. Correlations have been established between the variation of the main air pollutants and the main climate factors, highlighting the purifying role of rainfall. The index was calculated for Bucharest city, revealing similaritites for particulate matters and for $\mathrm{N}_{\text {ox }}$.

\section{CONCLUSIONS}

The air pollution index indicates, in a synthetic way, the monitoring stations of air quality which recorded monthly values over the alert threshold for certain pollutants, namely: nitrogen oxides, sediment particles and benzene from the Podu de Piatra area (Iasi 1 station).

\section{REFERENCES}

1. Apostol L, Vieru ND, Vieru PN (2012). Analysis of gaseous pollutants in the atmosphere of Botosani town. Present Environment and Sustainable Development 6(1):195204.

2. Apostol L (2007). The role of the meteo-climatic factors in the dispersion of atmospheric polluants, Present Environment and Sustenable Development 1:17-26.

3. Ioja C (2008). Metode si tehnici de evaluare a calitatii mediului in aria metropolitan a municipiului Iasi, editura Universitatii Bucuresti.

4. Oiste AM (2013). Analysis Of Air Pollutants In Iasi Town. Lucrări Ştiintifice 56(1). 